\title{
Application of Random Amplified Polymorphic Analysis for the Detection Genetic Variation in Tomato (Lycopersicon Esculentum Mill.)
}

\author{
Iyad Qassar ${ }^{*}$, Narmeen S. Ahmad* and Kadhim M. Ibrahim ${ }^{* *}$ \\ *Department of Biology, College of Science, Sulaimani University, \\ Sulaimani-Iraq. \\ *** Department of Biotechnology, College of Science, Al-Nahrain University, Baghdad-Iraq.
}

\section{Abstract}

This study was carried out to induce variations in tissue cultures of tomato (Lycopersicon esculentum Mill.) by using physical (gamma radiation) and chemical (sodium azide) mutagens.

Different plant growth regulators were tested for their potentials in callus induction, and shoot and root formation. Callus initiation on hypocotyl explants was achieved on Murashige and Skoog's (MS) medium supplemented with $0.1 \mathrm{mg} / 1$ 2, 4-dichlorophenoxyacetic acid (2, 4-D) and $0.5 \mathrm{mg} / \mathrm{l} \mathrm{6-}$ benzyl-aminopurine (BAP). Shoot regeneration was performed using hypocotyl explants cultured on MS medium containing $0.8 \mathrm{mg} / 1$ indole-3-acetic acid (IAA) and $2.0 \mathrm{mg} / \mathrm{l} \mathrm{BAP}$. Rooting was achieved on MS medium supplemented with $0.4 \mathrm{mg} / \mathrm{l}$ IAA. Callus cultures and seedlings were irradiated with gamma radiation at six doses $5,15,25,35,45$ or $55 \mathrm{mGy}$ from ${ }^{137} \mathrm{Cs}$ source, or treated with sodium azide(SA) at four concentrations $0.5,1.0,2.0$ or $3.0 \mathrm{mM}$ for 1,3 or 6 hours. Callus fresh weights were increased after irradiation with $25 \mathrm{mGy}$ gamma rays and treatment with (0.5 or 3.0$) \mathrm{mM}$ SA for 1 hour. Shoot regeneration was observed in all irradiated hypocotyl explants. Shoot regeneration at (15 and 35) mGy was similar to the control. Root formation was observed on hypocotyls irradiated with low doses (5 or 15) mGy only, while SA inhibited shoot and root regeneration. Random amplified polymorphic DNA (RAPD) technique was performed todetect genetic mutation in extracted DNA samples. DNA was extracted from mother plant, callus tissue, irradiated calli with 15 or $45 \mathrm{mGy}$ of gamma ray and calli treated with 0.5 and $3 \mathrm{mM} \mathrm{SA}$. Twelve arbitrary 10-mer primers were used of which eight primers gave amplification products. The total number of amplification products was 27 bands, of which 22 bands were monomorphic bands which indicates the presence of genetic mutations. One of these primers, C-02, revealed polymorphism in callus tissues treated with $45 \mathrm{mGy}$ of gamma radiation, 0.5 and $3.0 \mathrm{mM} \mathrm{SA}$. Others primers, C-08 and C-09, revealed polymorphisms in irradiated callus tissues with 15 mGy gamma radiation. RAPD was found to be effective technique to detect genetic mutations in callus tissue.

\section{Introduction}

The cultivated tomato (Lycopersicon esculentum Mill.) belongs to the Solanaceae family. Tomato is an ideal material as a model plant for physiological and classical genetic studies. Tomato is easy to cross with wild species and has a relatively short life cycle [1]. Nowadays, tomato has also become a model plant in molecular genetics, due to its small diploid genome $(2 n=24)$ [2] and the easiness for genetic transformation [3].

Mutation techniques in combination with tissue culture methods provide a powerful technology to improve plants. It is possible to upgrade well established plants by changing specific traits by inducing mutations [4, 5]. The advantages of in vitro mutagenesis are a large number of cells can be uniformly treated with physical or chemical mutagens. Selection pressure can be employed after the mutagen treatment to screen out mutant cells showing a new trait with relatively small effort, time, cost, and space requirements [6].

In mutagenesis of in vitro cultures, whether with chemical or physical mutagens, it is difficult to detect induced mutations in callus by morphological features [7]. Therefore, molecular markers were adopted, based on protein analysis (isozymes) or DNA polymorphisms (DNA markers) in order to detect genetic variation at the different stages of plant growth.

Random Amplified Polymorphic DNA (RAPD) assay is a modification of the basic polymerase chain reaction technique (PCR) that has been widely used as molecular markers since 1990 [8]. RAPD identification techniques can be used at any stage of plant 
development. They are not affected by environmental factors [9]. Therefore RAPD assay was used in this study to detect genetic variation after exposure of callus tissue to gamma irradiation and sodium azide.

\section{Materials and Methods \\ 1. Source of plants:}

Seeds of tomato (Lycopersicon esculentum Mill.) cv. "Pearson" were used as plant material. Seeds were first soaked in $70 \%(\mathrm{v} / \mathrm{v})$ ethanol for three minutes and rinsed three times with sterile distilled water, then surface sterilized using $5 \%(\mathrm{v} / \mathrm{v})$ of bleach for 10 minutes with vigorous shaking. They were rinsed in sterile distilled water three times then dried with sterilized filter paper. Seeds were transferred to the culture vessels containing half-strength Murashige and Skoog, (MS) medium [10]. The cultures were initially kept in darkness for 2 days at $25^{\circ} \mathrm{C}$ and then transferred to growth chamber under 16/8 hours (light/dark) photoperiod at light intensity of 1000 lux.

\section{Callus induction:}

The hypocotyls of aseptically germinated seedlings (10-12 day-old) were cut into $1 \mathrm{~cm}$ fragments. They were inoculated on MS medium and supplemented with different concentrations of the auxin 2, 4Dichlorophenoxyacetic acid (2, 4-D) $(0.0,0.1$, $0.5,1.0$ or 2.0$) \mathrm{mg} / \mathrm{l}$ and the cytokinin $6-$ Benzyl-aminopurine (BAP) $(0.0,0.5,1.0,2.0$, 3.0 or 4.0$) \mathrm{mg} / \mathrm{l}$. They were used to investigate the response of explants for callus induction.

\section{Shoot regeneration:}

The auxin Indole-3-acetic acid (IAA) $(0.0,0.2,0.4$ or 0.8$) \mathrm{mg} / \mathrm{l}$ and the cytokinin BAP $(0.0,0.5,1.0,1.5,2.0$ or 2.5$) \mathrm{mg} / 1$ were used to investigate the hypocotyl response to shoot regeneration and rooting. The cultures were incubated at $25^{\circ} \mathrm{C}$ for $16 / 8$ hours (light/dark) photoperiod at light intensity of 1000 lux.

\section{Irradiation of calli:}

Calli and in vitro grown seedlings were irradiated with seven different doses $(0,5,15$, $25,35,45$ or 55$) \mathrm{mGy}$ of gamma rays from a ${ }^{137}$ Cs source (Physics Department-College of Science, University of Sulaimani), at a rate of
$0.8 \mathrm{mGy} /$ hour. Irradiated and control calli were transferred to the callus induction medium containing $0.1 \mathrm{mg} / \mathrm{l} \quad 2,4-\mathrm{D}$ and $0.5 \mathrm{mg} / \mathrm{l} \mathrm{BAP}$. Irradiated and non irradiated hypocotyls were cultured on MS medium containing $0.8 \mathrm{mg} / \mathrm{l} \mathrm{IAA}$ and $1.5 \mathrm{mg} / \mathrm{l} \mathrm{BAP}$.

\section{Treatment of calli with sodium azide:}

Calli were subjected to different concentrations of SA $(0.0,0.5,1.0,2.0$ or $3.0 \mathrm{mM}, \mathrm{pH} 3.0$ ) for three durations of exposure (1, 3 or 6) hours. Following treatment, the calli were washed with MS liquid medium and transferred to callus induction medium containing $0.1 \mathrm{mg} / \mathrm{l} 2$, 4-D and $0.5 \mathrm{mg} / \mathrm{l} \mathrm{BAP}$.

\section{Statistical analyses:}

A completely randomized design (CRD) with 10 replicates per treatment, and then Duncan's multiple range tests were used to compare the means at a probability of $\leq 0.05$ [11].

\section{Genomic DNA extraction and purification Modified from: [12-15].}

Approximately $2 \mathrm{~g}$ of tissue from callus and seedlings was submerged in $5 \mathrm{ml}$ of alcohol for 30 minutes. Alcohol was allowed to evaporate, and then the tissues were ground with a mortar and pestle. The homogenized tissues were transferred to $600 \mu \mathrm{l}$ of prewarmed 2X CTAB DNA extraction buffer with $2 \%(\mathrm{v} / \mathrm{v})$ B-mercaptoethanol in $1.5 \mathrm{ml}$ Eppendorf tubes, incubated for $1 \mathrm{hr}$ at $55^{\circ} \mathrm{C}$ in a water bath, with occasional mixing by gentle swirling.

The homogenate was removed from the water bath, an equal volume of phenol: chloroform: isoamyl alcohol $(25: 24: 1)$ was added to the solution, and mixed well by shaking tubes for $15 \mathrm{~min}$. The emulsified mixture was centrifuged at $13,000 \mathrm{rpm}$ for $10 \mathrm{~min}$, and then the aqueous phase placed into new Eppendorf tubes. Equal volume of chloroform: isoamyl alcohol (24:1) was added to aqueous phase, and then centrifuged at $13,000 \mathrm{rpm}$ for $10 \mathrm{~min}$. The upper phase was eluted then transferred to new tubes.

Cold ammonium acetate (7.5 M, 0.08 volumes) and cold isopropanol (0.54 volumes) were added, incubated for $1 \mathrm{hr}$ at $20^{\circ} \mathrm{C}$ then centrifuged at $13,000 \mathrm{rpm}$ for 
5 min. The precipitated DNA was washed with $700 \mu \mathrm{l}$ of cold $70 \% \quad(\mathrm{v} / \mathrm{v})$ of ethanol, centrifuged at 13,000 rpm for 1 min and then the supernatant was discarded. DNA was air dried and dissolved in $100 \mu \mathrm{l}$ of TE buffer and stored at $-20^{\circ} \mathrm{C}$.

\section{Preparation of RAPD reactions}

RAPD assay was carried out on genomic DNA. Twelve arbitrary 10-mer primers were used in this study (Table (1)). The standard $25 \mu \mathrm{l}$ PCR reaction mixture was prepared after optimization of parameters for RAPD assay. It consisted of $1 \mathrm{X}$ Taq buffer, $2.5 \mathrm{mM}$ $\mathrm{MgCl}_{2}, 7.5$ picomoles primer, $200 \mu \mathrm{M}$ dNTPs, $2 \mathrm{U}$ of $\mathrm{Taq}$ polymerase and template DNA (Fermentas-USA). The standard PCR conditions used for testing the different parameters were consisted of initial denaturing temperature $\left(3 \mathrm{~min}\right.$ at $94^{\circ} \mathrm{C}$ ) followed by 40 cycles of $1 \mathrm{~min}$ at $94^{\circ} \mathrm{C}, 30$ seconds at $36^{\circ} \mathrm{C}$ (annealing temperature), $1 \mathrm{~min}$ and $30 \mathrm{sec}$ at $72^{\circ} \mathrm{C}$ (extension temperature) with a final extension of $7 \mathrm{~min}$ at $72^{\circ} \mathrm{C}$. Amplification products were separated on $2 \%$ agarose gel in 1X TBE buffer [16].

Table (1)

Arbitrary 10-mer Primers used in this study.

\begin{tabular}{|c|c|}
\hline $\begin{array}{c}\text { *Primer } \\
\text { name }\end{array}$ & $\begin{array}{c}\text { Primer sequence } \\
\left(\mathbf{5}^{\prime} \text { - } \mathbf{3}^{\prime}\right)\end{array}$ \\
\hline \hline A-02 & TGCCGAGCTG \\
\hline \hline A-05 & AGGGGTCTTG \\
\hline A-012 & TCGGCGATAG \\
\hline A-015 & TTCCGAACCC \\
\hline B-04 & GGACTGGAGT \\
\hline B-10 & CTGCTGGGAC \\
\hline \hline C-02 & GTGAGGCGTC \\
\hline \hline C-07 & GTCCCGACGA \\
\hline \hline C-09 & CTCACCGTCC \\
\hline \hline C-08 & TGGACCGGTG \\
\hline C-12 & TGTCATCCCC \\
\hline C-18 & $\begin{array}{c}\text { TGAGTGGG } \\
\text { TG }\end{array}$ \\
\hline
\end{tabular}

*All primers were purchased from Sigma-Germany

\section{Results and Discussion}

\section{Callus induction}

The hypocotyl explants grown in most media formed callus within 10 days. Callus started from the wounded end and spread toward the middle region of the explants.

Table (2) shows the effect of 2, 4-D and BAP concentrations in combination on callus fresh weight forming on hypocotyl explants cultured on MS medium for 30 days. Callus formation was observed in all 2, 4-D and BAP combination treatments. However, maximum callus weight $(2.28 \mathrm{~g})$ was obtained when the hypocotyl explants were cultured on MS medium containing $0.1 \mathrm{mg} / \mathrm{l} \quad 2,4-\mathrm{D}$ and $0.5 \mathrm{mg} / \mathrm{l} \mathrm{BAP}$ (Fig. (1)).

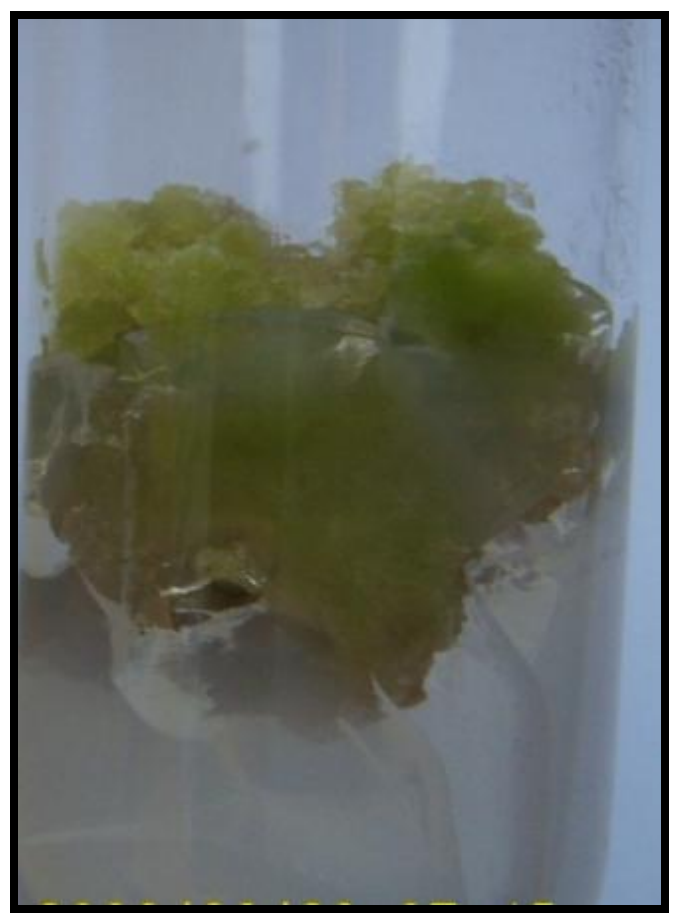

Fig. (1) Callus induction on hypocotyl explants produced on MS medium supplemented with $0.1 \mathrm{mg} / \mathrm{l} 2,4-D$ and $0.5 \mathrm{mg} / \mathrm{l} \mathrm{BAP}$. 
Table (2)

Effect of different concentrations of 2, 4-D and BAP and their interaction on callus fresh weight (g) initiated on hypocotyl explants of L. esculentum, 30 days in culture.

\begin{tabular}{|c|c|c|c|c|c|c|}
\hline \multirow[t]{2}{*}{$2,4-D(\mathrm{mg} / \mathrm{l})$} & \multicolumn{6}{|c|}{$B A P(m g / l)$} \\
\hline & 0.0 & 0.5 & 1.0 & 2.0 & 3.0 & 4.0 \\
\hline 0.0 & $\mathrm{Oh}^{*}$ & $0.23 \mathrm{gh}$ & $1.05 \mathrm{cde}$ & $1.09 \mathrm{cde}$ & $1.09 \mathrm{cde}$ & $1.39 \mathrm{~cd}$ \\
\hline 0.1 & $0.34 \mathrm{gh}$ & $2.28 \mathrm{a}$ & $1.93 \mathrm{~b}$ & $1.18 \mathrm{cde}$ & $1.26 \mathrm{cde}$ & $1.08 \mathrm{cde}$ \\
\hline 0.5 & $1.19 \mathrm{cde}$ & $1.28 \mathrm{~cd}$ & $1.44 \mathrm{c}$ & $0.97 \mathrm{cde}$ & $1.09 \mathrm{cde}$ & 0.75 ef \\
\hline 1.0 & $1.43 \mathrm{c}$ & $0.88 \mathrm{de}$ & $0.48 \mathrm{fg}$ & $0.35 \mathrm{gh}$ & $0.27 \mathrm{gh}$ & $0.11 \mathrm{gh}$ \\
\hline
\end{tabular}

*Means designated with the same letter(s) do not differ significantly from each other according to Duncan's multiple range tests, $P \leq 0.05$. This will apply for subsequent tables.

A reduction in callus weight was noticed with progressive increasing of 2, 4-D and BAP concentrations. It is obvious from (Table (2)) that both 2, 4-D as well as BAP were essential for callus induction in $L$. esculentum but significantly were more effective when used in combinations. These results are in agreement with the results of others [17-20].

Skoog and Miller [21] suggested that at balanced ratio of auxin and cytokinin, the tissue grows as disorganized callus.

\section{Shoot regeneration}

Shoot regeneration was obtained by culturing in vitro grown hypocotyls on different levels of IAA and BAP. Regeneration started nearly 10 days after cultivation. The number and length of shoots differed depending on the type and concentration of growth regulators added to the regeneration medium.

The results obtained in the present work indicate that auxin and cytokinin in combination provide the higher number of shoots/explant than if they were added separately (Table (3)). The optimum ration was $0.8 \mathrm{mg} / \mathrm{l}$ IAA and $2.0 \mathrm{mg} / \mathrm{l} \mathrm{BAP}$ as indicated by number of shoots/explant produced (Fig.(2)). Skoog and Miller [21] suggested that shoot or root regeneration is dependent on the ration of auxin to cytokinin in the culture medium. Low auxin to cytokinin ratio lead to the formation of shoots, whereas high auxin to cytokinin ratio stimulate the formation of roots. The present data are in agreement with those of others [3, 17, 22-26] who determined that the most efficient medium for in vitro regeneration of tomato is that which supplemented with low concentration of IAA and higher levels of BAP.

Table (3)

Effect of different concentrations of IAA and $B A P$ and their interaction on shoots number/ explant obtained from hypocotyl of $L$. esculentum, six weeks in culture.

\begin{tabular}{|c|c|c|c|c|c|c|}
\hline \multirow{2}{*}{$\begin{array}{c}I A A \\
(m g / l)\end{array}$} & \multicolumn{6}{|c|}{$B A P(m g / l)$} \\
\hline & 0.0 & 0.5 & 1.0 & 1.5 & 2.0 & 2.5 \\
\hline 0.0 & $0 \mathrm{~b}^{*}$ & $0 \mathrm{~b}$ & $0.1 \mathrm{~b}$ & $\begin{array}{c}0.88 \\
\mathrm{ab}\end{array}$ & $\begin{array}{c}0.56 \\
a b\end{array}$ & $\begin{array}{c}0.06 \\
b\end{array}$ \\
\hline 0.2 & $\begin{array}{c}0.49 \\
\mathrm{ab}\end{array}$ & $\begin{array}{c}0.86 \\
a b\end{array}$ & $\begin{array}{c}0.64 \\
\mathrm{ab}\end{array}$ & $\begin{array}{c}0.14 \\
b\end{array}$ & $\begin{array}{c}0.44 \\
\mathrm{ab}\end{array}$ & $\begin{array}{c}0.4 \\
a b\end{array}$ \\
\hline 0.4 & $\begin{array}{c}0.46 \\
\mathrm{ab}\end{array}$ & $\begin{array}{c}1.08 \\
\mathrm{ab}\end{array}$ & $0.1 \mathrm{~b}$ & $\begin{array}{c}0.72 \\
\mathrm{ab}\end{array}$ & $\begin{array}{c}0.22 \\
a b\end{array}$ & $\begin{array}{c}0.66 \\
a b\end{array}$ \\
\hline 0.8 & $\begin{array}{c}0.3 \\
\mathrm{ab}\end{array}$ & $0 \mathrm{~b}$ & $\begin{array}{c}1.12 \\
\mathrm{ab}\end{array}$ & $\begin{array}{c}1.18 \\
\mathrm{a}\end{array}$ & $\begin{array}{c}1.06 \\
\mathrm{ab}\end{array}$ & $\begin{array}{c}0.62 \\
a b\end{array}$ \\
\hline
\end{tabular}




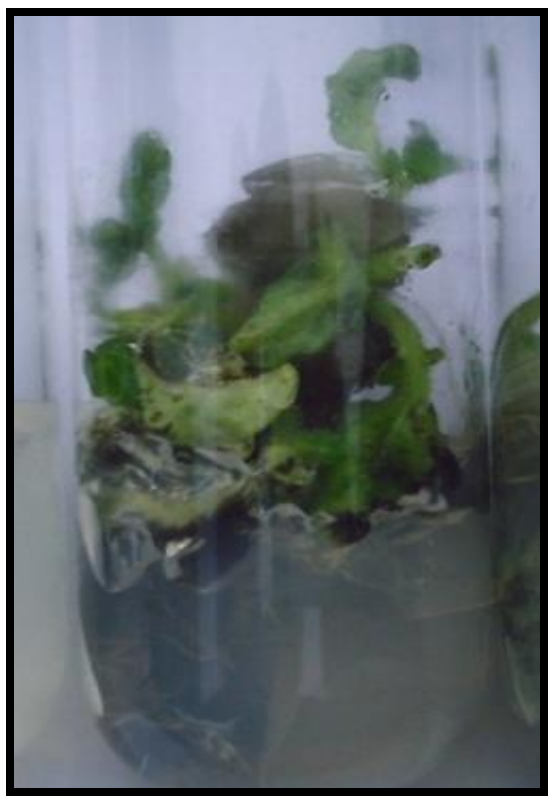

Fig. (2) Shoot regeneration obtained on hypocotyl explants of L. esculentum on MS medium supplemented with $0.8 \mathrm{mg} / \mathrm{l} \mathrm{IAA}$ and

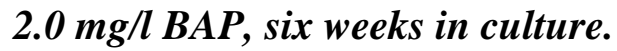

Sheeja et al. [26] examined IAA, BAP and Kin on tomato shoot regeneration, a low level of IAA with high levels of BAP or Kin was the optimum.

In terms of shoot elongation, in the presence of IAA and BAP together in the medium, shoot elongation varied (Table (4)).

Table (4)

Effect of different concentrations of IAA and $B A P$ and their interaction on shoot length (cm)/ explant obtained from hypocotyl of L. esculentum, six weeks in culture.

\begin{tabular}{|c|c|c|c|c|c|c|}
\hline \multirow{2}{*}{$\begin{array}{c}I A A \\
(m g / l)\end{array}$} & \multicolumn{6}{|c|}{$B A P(m g / l)$} \\
\hline & 0.0 & 0.5 & 1.0 & 1.5 & 2.0 & 2.5 \\
\hline 0.0 & $\begin{array}{c}0 \mathrm{~d} \\
*\end{array}$ & $0 \mathrm{~d}$ & $\begin{array}{l}0.8 \\
\text { bcd }\end{array}$ & $\begin{array}{c}0.8 \\
\text { bcd }\end{array}$ & $\begin{array}{c}1.2 \\
\text { bcd }\end{array}$ & $\begin{array}{l}0.2 \\
\mathrm{~cd}\end{array}$ \\
\hline 0.2 & $\begin{array}{l}0.6 \\
\mathrm{~cd}\end{array}$ & $1 \mathrm{bcd}$ & $\begin{array}{l}1.2 \\
\text { bcd }\end{array}$ & $\begin{array}{c}0.4 \\
\mathrm{~cd}\end{array}$ & $\begin{array}{l}1.2 \\
\text { bcd }\end{array}$ & $\begin{array}{l}1.6 \\
b c\end{array}$ \\
\hline 0.4 & $\begin{array}{c}0.4 \\
\mathrm{~cd}\end{array}$ & $\begin{array}{l}0.8 \\
\text { bcd }\end{array}$ & $\begin{array}{l}0.4 \\
\mathrm{~cd}\end{array}$ & $2 b$ & $\begin{array}{l}0.4 \\
\mathrm{~cd}\end{array}$ & $\begin{array}{l}0.8 \\
\text { bcd }\end{array}$ \\
\hline 0.8 & $\begin{array}{l}0.2 \\
\text { cd }\end{array}$ & $0 \mathrm{~d}$ & $1 \mathrm{bcd}$ & $\begin{array}{l}1.2 \\
\text { bcd }\end{array}$ & $3.2 \mathrm{a}$ & $\begin{array}{l}0.8 \\
\text { bcd }\end{array}$ \\
\hline
\end{tabular}

The highest shoot length $(1.18 \mathrm{~cm})$ was obtained at $0.8 \mathrm{mg} / \mathrm{l} \mathrm{IAA}$ and $1.5 \mathrm{mg} / \mathrm{l} \mathrm{BAP}$. Shoot development was neither observed on hormone-free medium nor media containing $0.5 \mathrm{mg} / \mathrm{l} \mathrm{BAP}$, and also, $0.8 \mathrm{mg} / \mathrm{l} \mathrm{IAA}$ combined with $0.5 \mathrm{mg} / \mathrm{l} \mathrm{BAP}$. It is to be mentioned that shoot elongation on L. esculentum hypocotyls is dependent on the application of exogenous auxin and cytokinin. Tran Thanh Van [27] and Baraldi et al. [28] suggested that the most important step in regeneration of any plant material through tissue cultures depends on the successful adjustment of the type and combination of plant growth regulators. It is worth mentioning that hypocotyls of $1 \mathrm{~cm}$ long were transferred to MS medium supplemented with IAA, BAP or their combination; rhizogenesis occurred followed by elongation of the shoots. Some hypocotyl explants started rooting directly without forming shoots. Rooting was recorded after six weeks of culture.

Table (5) represents the interaction between IAA and BAP on the number of roots/explant. The response for rooting was poor to IAA and BAP combinations. No root formation was observed when the medium supplemented with high amount of BAP. Also, there was no root formation on control treatment.

These results agree with those of (Öktem et al.) [3]. The highest number of roots/explant on a medium supplemented with IAA and BAP combination was recorded at $0.4 \mathrm{mg} / \mathrm{l}$ IAA and $0.0 \mathrm{mg} / \mathrm{l} \mathrm{BAP}$; it was 10.4 (Table (5), Fig. (3)).

Table (5)

Effect of the different concentrations of IAA and $B A P$ and their interaction on root number/explant grown on MS medium, six weeks in culture.

\begin{tabular}{|c|c|c|c|c|c|c|}
\hline \multirow{2}{*}{$\begin{array}{c}I A A \\
(m g / l) \\
\end{array}$} & \multicolumn{6}{|c|}{$B A P(m g / l)$} \\
\hline & 0.0 & 0.5 & 1.0 & 1.5 & 2.0 & 2.5 \\
\hline 0.0 & $0 \mathrm{e}^{*}$ & $\begin{array}{c}0.6 \\
\text { de }\end{array}$ & $\begin{array}{c}0.4 \\
\mathrm{e}\end{array}$ & $\begin{array}{c}1 \\
\text { cde }\end{array}$ & $0 \mathrm{e}$ & $0 \mathrm{e}$ \\
\hline 0.2 & $\begin{array}{l}3.8 \\
\mathrm{bc}\end{array}$ & $\begin{array}{l}1.4 \\
\text { cde }\end{array}$ & $\begin{array}{c}1 \\
\text { cde }\end{array}$ & $\begin{array}{l}1.6 \\
\text { cde }\end{array}$ & $0 \mathrm{e}$ & $\begin{array}{c}1 \\
\text { cde }\end{array}$ \\
\hline 0.4 & $\begin{array}{c}10.4 \\
\mathrm{a}\end{array}$ & $\begin{array}{l}3.6 \\
\text { bcd }\end{array}$ & $\begin{array}{c}1 \\
\text { cde }\end{array}$ & $\begin{array}{l}1.2 \\
\text { cde }\end{array}$ & $\begin{array}{c}1 \\
\text { cde }\end{array}$ & $\begin{array}{c}0.4 \\
\mathrm{e}\end{array}$ \\
\hline 0.8 & $\begin{array}{c}4.8 \\
\mathrm{~b}\end{array}$ & $\begin{array}{c}2.6 \\
\text { bcde }\end{array}$ & $\begin{array}{c}2 \\
\text { cde }\end{array}$ & $\begin{array}{c}3.2 \\
\text { bcde }\end{array}$ & $\begin{array}{c}2.8 \\
\text { bcde }\end{array}$ & $0 \mathrm{e}$ \\
\hline
\end{tabular}




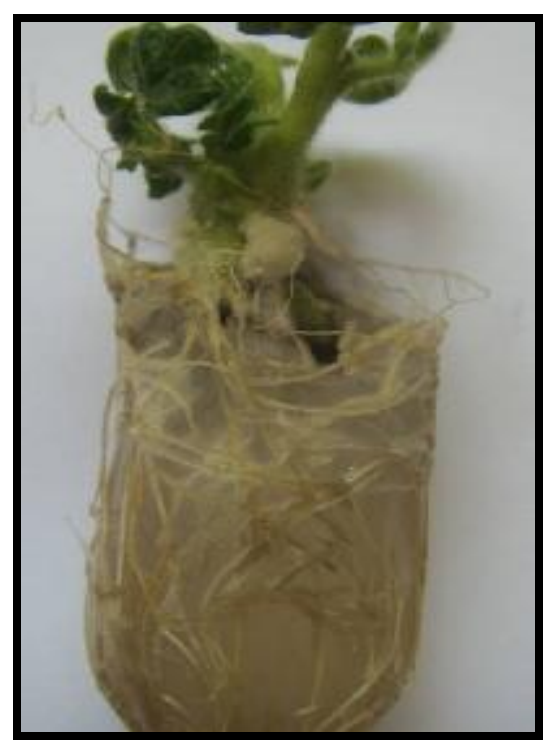

Fig. (3) Root regeneration obtained on shoots obtained from hypocotyl explants cultured on MS medium containing $0.4 \mathrm{mg} / \mathrm{l} \mathrm{IAA}$, six weeks in culture.

It was apparent that a low amount of exogenous IAA was sufficient to promote rooting on tomato in vitro shoots.

Cytokinins and IAA have antagonistic roles in root development; auxin promotes the formation of lateral and adventitious roots, whereas cytokinins inhibit root formation and reverses the IAA effect [29].

\section{Induction of mutation in callus cultures}

Results indicated a decrease in callus fresh weight with increasing dose of gamma radiation. Conversely, a sudden stimulatory effect was obtained, as revealed by the slight increase in callus mass $(2.12 \mathrm{~g})$ at a radiation dose of $(25 \mathrm{mGY})$. Maximum reduction in callus fresh weight was observed at $55 \mathrm{mGy}$ (Fig.(4)).

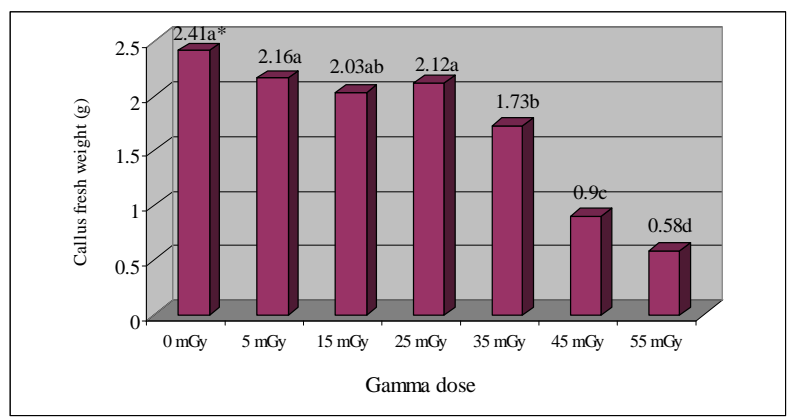

Fig. (4) Influence of gamma irradiation on callus fresh weight cultured on MS medium containing $0.1 \mathrm{mg} / \mathrm{l} \mathrm{2,} \mathrm{4-D}$ and $0.5 \mathrm{mg} / \mathrm{l} \mathrm{BAP \text {, }}$ after 30 days of irradiation.
Several studies investigated the effects of gamma irradiation on plant cell. Gamma irradiation caused inhibition of tissue culture growth with failure of RNA and protein synthesis in bean [30].

Similar results in reduction of callus weight due to the effect of gamma radiation on bean [30], barley [31], sweet potato [32], sunflower [33], and sugarcane [34], have been documented.

It was reported that the causes in callus growth retardation were the result of arresting cell division in mitosis [35], physiological damage or protein oxidation [36]. Gamma radiation causes oxidative stress and affects biomolecules by causing conformational changes, oxidation, rupture of covalent bonds, and formation of free radicals. The hydroxyl and superoxide anion radicals that are generated by radiation could modify the molecular properties of the proteins causing oxidative modifications of the proteins. Chemical changes of the proteins that are caused by gamma irradiation are fragmentation, cross-linking, aggregation and oxidation caused by oxygen radicals which are generated by water radiolysis [37].

Both beneficial and harmful effects on callus fresh weight were observed after SA treatment. Callus fresh weight was affected by SA in all treatments (Table (6)).

Table (6)

Effect of different concentrations of sodium azide at three periods on callus fresh weight (g) of L. esculentum cultures grown on MS medium containing $0.1 \mathrm{~m} / \mathrm{l} 2,4-D$ and $0.5 \mathrm{mg} / \mathrm{l} \mathrm{BAP,} 30$ days after treatment.

\begin{tabular}{|c||c|c||c||}
\hline \multicolumn{1}{|c||}{ SA (mM) } & \multicolumn{3}{|c|}{ Time (hour) } \\
\hline \hline & $\mathbf{1}$ & $\mathbf{3}$ & $\mathbf{6}$ \\
\hline \hline $\mathbf{0 . 0}$ & $1.72 \mathrm{a}^{*}$ & $1.59 \mathrm{a}$ & $1.16 \mathrm{~b}$ \\
\hline \hline $\mathbf{0 . 5}$ & $1.25 \mathrm{~b}$ & $0.12 \mathrm{c}$ & $0.11 \mathrm{c}$ \\
\hline \hline $\mathbf{1 . 0}$ & $0.14 \mathrm{c}$ & $0.18 \mathrm{c}$ & $0.07 \mathrm{c}$ \\
\hline \hline $\mathbf{2 . 0}$ & $0.20 \mathrm{c}$ & $0.21 \mathrm{c}$ & $0.16 \mathrm{c}$ \\
\hline \hline $\mathbf{3 . 0}$ & $1.25 \mathrm{~b}$ & $0.12 \mathrm{c}$ & $0.06 \mathrm{c}$ \\
\hline
\end{tabular}


Previously, Ganesan et al. [38] recorded stimulation of cotton somatic embryogenic by SA treatment and suggested that callus stimulation was due to altering gene expression where new isozymes bands appeared in treated cultures. Hofmann et al. [39] subjected soybean embryogenic culture to ethyl methyl sulphonate (EMS) $(0,1,3,10$ or $30 \mathrm{mM}$ ), and found a decrease in survival rate of embryogenic culture with increasing concentrations of EMS.

\section{Induction of mutation in regenerated shoots}

In control and irradiated plants, regeneration was observed in all dosages. However, there is no significant difference between the control plant and those were irradiated with $15 \mathrm{mGy}$ or $35 \mathrm{mGy}$ (Fig. 5). Shoot number/ hypocotyl in explants that were irradiated with $(5,25,45$ or 55$) \mathrm{mGy}$ reduced to $(1.2,0.4,1$ and 0.4$)$, respectively. The results proved that the reduction in shoot number/explant was not proportional with increasing gamma dosages. Number of regenerated plantlets irradiated with $15 \mathrm{mGy}$ or $35 \mathrm{mGy}$ approached the same number of control.

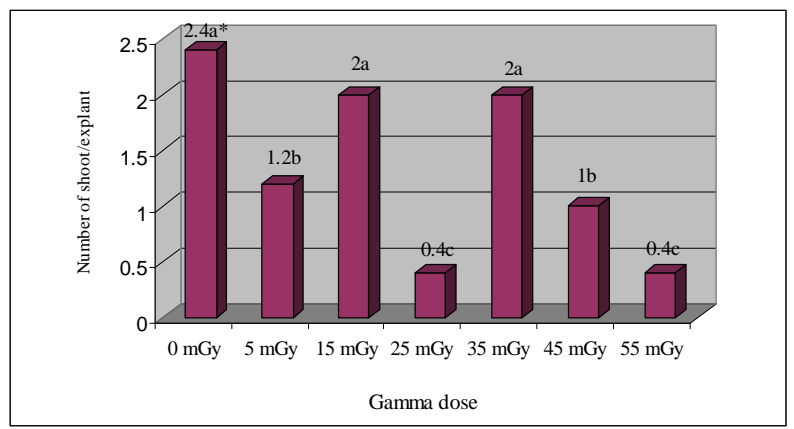

Fig. (5) Influence of gamma irradiation on shoot number obtained from 11 irradiated hypocotyl explants of $L$. esculentum cultured on MS medium supplemented with $0.8 \mathrm{mg} / \mathrm{l}$ IAA and $1.5 \mathrm{mg} . /$ l BAP, six weeks in culture.

The influence of gamma irradiation on shoot length/explant is shown in (Fig. (6)).

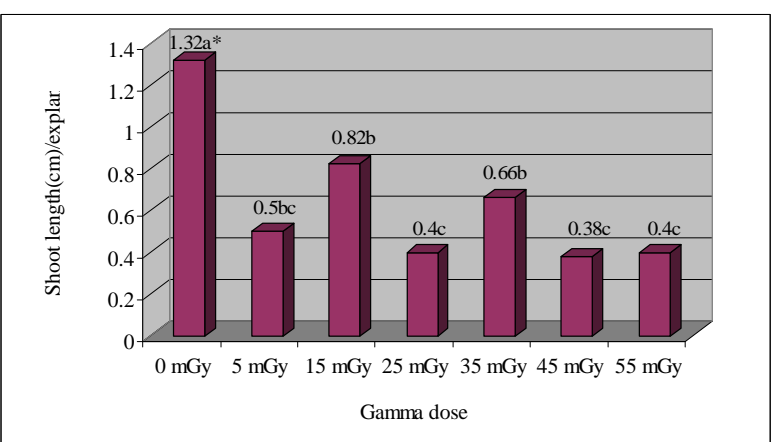

Fig. (6) Influence of gamma irradiation on shoot length obtained from irradiated

hypocotyl explant of L. esculentum cultured on MS medium supplemented with $0.8 \mathrm{mg} / \mathrm{l} \mathrm{IAA}$ and $1.5 \mathrm{mg} / \mathrm{l} \mathrm{BAP}$, six weeks in culture.

The decrease in shoot length/explant in relation to the control was observed in every treated culture. The shoot length/explant was high in plants which irradiated with $15 \mathrm{mGy}$ and $35 \mathrm{mGy}$ as compared to other irradiated plants.

Maximum shoot lengths (0.82 and 0.66) $\mathrm{cm}$ was recorded at the gamma doses of 15 and $35 \mathrm{mGy}$, respectively. The effects of 25 , 45 , and $55 \mathrm{mGy}$ were equal in the reduction of shoot length/explant. It is clear that the reduction in shoot length was not related to the doses of gamma.

\section{Root formation}

To estimate the effectiveness of gamma irradiation on root initiation, irradiated hypocotyls were cultured on MS medium for six weeks. Root number/explant was highly affected by gamma irradiation as shown in (Fig. (7)). There was a significant difference in root number/explant between control hypocotyls and irradiated ones. Roots were observed only at 5 and $15 \mathrm{mGy}$; the root number/explant was 6 and 12, respectively. On other hand, other gamma doses caused inhibition in root formation. 


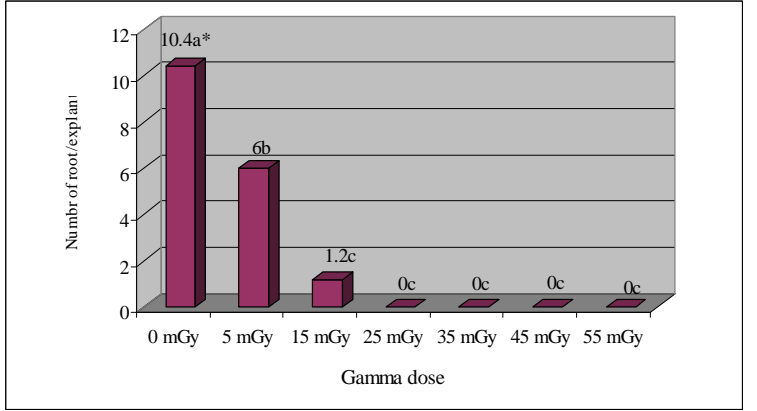

Fig.(7) Influence of gamma irradiation on root number obtained from irradiated hypocotyl explants of L. esculentum cultured on MS medium, six weeks in culture.

\section{Random amplified polymorphic DNA (RAPD)}

RAPD technique was used to investigate polymorphisms at DNA levels in tomato mother plant, callus tissue, irradiated calli with 15 or $45 \mathrm{mGy}$ of gamma rays, and treated calli with 0.5 and $3 \mathrm{mM} \mathrm{SA}$ (Fig. (8, a, b, and c)). DNA was amplified with 12 random 10-mer primers. Out of these, only 8 primers produced clear reproducible bands. The total amplification products generated by these primers were 27 bands ranged from $220 \mathrm{bp}$ in primer C-07 to approximately $1500 \mathrm{bp}$ in primers A-015 and C-09. Monomorphic bands were generated by the primers A-05, A-015, B-10, C-07 and C-18. Other primers, C-02, C08 and C-09, revealed polymorphic bands.

The obtained results confirmed the usefulness and suitability of RAPD technique for screening of mutations after application of gamma radiation and SA on callus tissues. There were no polymorphisms between the mother plant and non treated callus, this indicating the genetic stability of the callus tissue after subculturing on MS medium containing $0.1 \mathrm{mg} / \mathrm{l} 2,4-\mathrm{D}$ and $0.5 \mathrm{mg} / \mathrm{l} \mathrm{BAP}$.

Primers (C-02, C-08, and C-09) have revealed polymorphic fragments in irradiated calli, while primer, C-02, generated polymorphism in treated calli with SA. These polymorphisms indicate the presence of genetic differences in tomato calli treated with gamma radiation and $\mathrm{SA}$. It is possible that these mutations have occurred in different loci. Sources of polymorphisms in RAPD assay may include a base change within priming site sequence, deletions of priming site, insertions that render priming sites too distant to support amplification and deletions or insertions that change the size of a DNA fragment without preventing its amplification [8]. Gamma radiation induces mutations by ejecting atom from the tissues and it causes addition, deletion, transition, and transversion in DNA. SA causes transitions in DNA nucleotides [37].

Induction of mutation in plant was observed by many investigators who detected the polymorphisms by RAPD assay. Atanassov et al. [40] used gamma rays and SA to create somaclonal mutation in barley. They suggested that RAPD assay is a sensitive and representative approach to distinguish the variability created by tissue culture and mutagenesis.
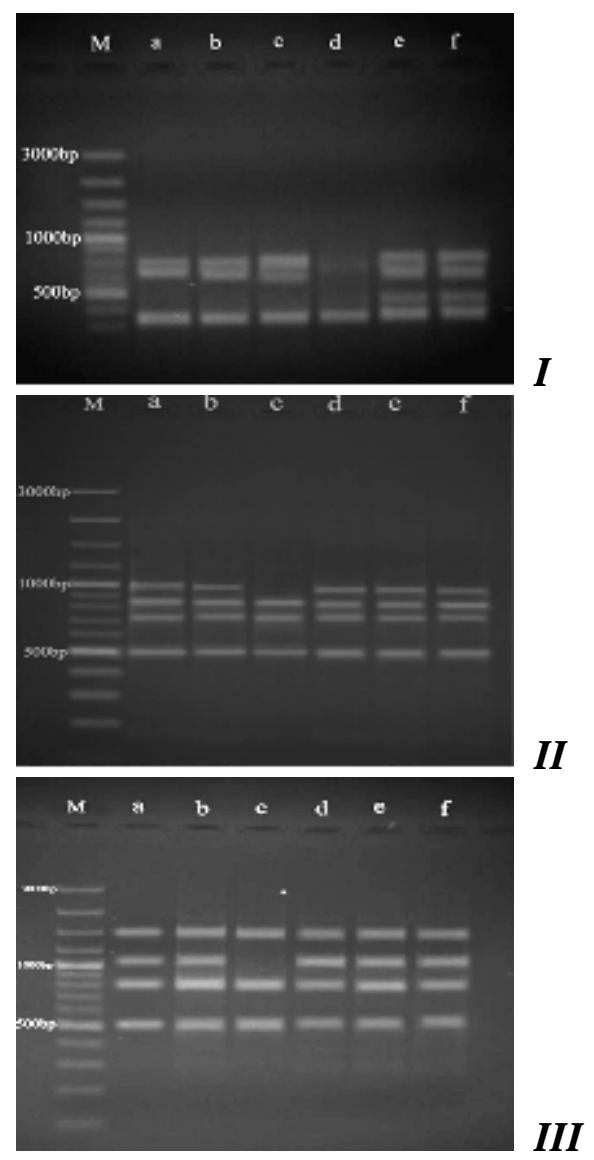

Fig. (8) RAPD profile of L. esculentum generated by primers I: C-02, II:C-08, III: $C$-09, $M=100$ bp ladder, lane (a) mother plant, (b) callus tissue, (c) irradiated calli with 15 (d) 45 mGy of gamma rays, (e) treated calli with 0.5 and $(f) 3.0 \mathrm{mM}$ sodium azide. 


\section{References}

[1] Dielen, V., Lecouvet, V., Dupont, S., and Kinet, J. (2001). In vitro control of floral transition in tomato (Lycopersicon esculentum Mill.), the model for autonomously flowering plants, sing the late flowering unilflora mutant. Journal of Experimental Botany, 52(357):715-723.

[2] Kulawiec, M., Tagashira, N., Plader, W., Bartoszewski, G., Kuc, D., Sniezko, R., and Malepszy, S. (2003). Chromosome number variation in somatic hybrids between transgenic tomato (Lycopersicon esculentum) and Solanum lycopersicoides. Journal Applied Genetic, 44(4):431-447.

[3] Öktem, H.A., Bülbül, Y., Öktem, E., and Yücel, M. (1999). Regenerating and agrobacterium-mediated transformation studies in tomato (Lycopersicon esculentum Mill). Turkish Journal of Botany, 23:345-348.

[4] Mujib, A. (2005). Colchicine induced morphological variants in pineapple. Plant Tissue Culture and Biotechnology, 15(2):127-133.

[5] Myint, K.S., Aung, K.O., and Soe, K. (2005). Development of a short duration upland rice mutant line through anther culture of gamma irradiated plants. In: Mutation Breeding Newsletter and Review. Joint FAO/IAEA Division of Nuclear Techniques.

[6] Hossain, Z., Mandal, A.K.A., Datta, S.K., and Biswaas, A.K. (2006). Isolation of a $\mathrm{NaCl}$-tolerant of Chrysanthemum morifolium by gamma radiation: in vitro mutagenesis and selection by salt stress. Functional Plant Biotechnology, 33:91101.

[7] Saif-Ur-Rasheed, M., Assad, S., Zafar, Y., and Waheed (1998). Use of radiation and in vitro techniques for development of salt tolerant mutants in sugarcane and potato. In: In Vitro Techniques for Selection of Radiation Induced Mutations Adapted to Adverse Environmental Conditions. Proceeding of a Final Research Coordination Meeting organized by the Joint FAO/IAEA Division of Nuclear Techniques in Food and Agriculture, Shanghai, China. Pp. 61-74, IAEA, Veinna (2001).
[8] Williams, J.G.K., Kubelik, A.R., Livak, K.J., Rafalski, J.A., and Tingey, A.V. (1990). DNA polymorphisms amplified by arbitrary primers are useful as genetic markers. Nucleic Acids Researches, 18:6531-6535.

[9] Lisek, A., Korbin, M., and Rozpara, E. (2006). Using simply generation RAPD markers to distinguishing between sweet cherry (Prunus avium L.) cultivars. Journal of Fruit and Ornamental Plant Research, 14:53-59.

[10] Murashige, T., and Skoog, F., (1962). A revised medium for rapid growth and bioassay with tobacco tissue culture. Physiol. Plant. 15:473,-497.

[11] Al-Rawi, Kh.M. and Khalaf-Allah, A. (1980). Design and Analysis of Agricultural experiments. Ministry of Higher education and scientific Research, University of Mosul, Iraq. (In Arabic).

[12] Doyle, J.J., and Doyle, J.L. (1987). A rapid DNA isolation procedure for small quantities of fresh leaf tissue. Photochemistry Bulletin, 19:11-15.

[13] Edwards, K., Johnstone, C., and Thompson, C. (1991). A simple and rapid method for the preparation of plant genomic DNA for PCR analysis. Nucleic Acids Researches, 19(6):13-49.

[14] Lin, R. C., Ding, Z. S., Li, L. B., and Kuang, T.Y., (2001). A rapid and efficient DNA minipreparation suitable for screening transgenic plants. Plant Molecular Biology Reporter, 19:379a379e.

[15] Sharma, R., Mahler, H.R., Mohapatra, T., Bhargava, S.C., and Sharma, M.M. (2003). Isolation plant genomic DNA without liquid nitrogen. Plant Molecular Biology Reporter. 21:43-50.

[16] Rajput, S.G., Wable, K.J., Sharma, K.M., Kubde, P.D., and Mulay, S.A. (2006). Reproducibility testing of RAPD and SSR markers in tomato. African Journal of Biotechnology, 5(2):108-112.

[17] Chaudary, Z., Feroz, I., Ahmed, W., Rashid, H., Mirza, B., and Quraishi, A. (2001). Varietals response of Lycopersicon esculentum L. to callogenesis and regeneration. Journal of Biological Sciences, 1(19):1138-1140. 
[18] El-Sayed, N.E., El-Aref, H.M., Taghin, A.S., and Hashad, M.M. (2002). Molecular genetic markers in tomato somaclonal selected for drought tolerance. Assiut Journal Agriculture Science, 33(5):159180.

[19] Rzepka-Plevneš, D., Kulpa, D., Grabiec, M., Kowalczys, K., and Kurek, J. (2006). The effect of growth regulators and culture conditions on the callus induction in tomato Lycopersicon sp. Acta Sci. Pol., Hortorum Culture, 5(2):23-34.

[20] Hassanein, A.M. (2004). Effect of relativity high concentration of mannitol and sodium chloride on regeneration and gene expression of stress tolerant (Alhagi graecorum) and stress sensitive (Lycopersicon esculentum L.) plant species. Journal Plant Physiology, 30:19-36.

[21] Skoog, F., and Miller, C.O. (1957). Chemical control of growth and bud formation in tobacco segment and callus cultured in vitro. Journal Botany, 35:782-790.

[22] Sheeja, T.E., and Mandal, A.B. (2003). In vitro flowering and fruiting in tomato (Lycopersicon esculentum Mill.). Asia Pacific Journal of Molecular Biology and Biotechnology, 11(1):37-42.

[23] Garcia-Reina, G., and Luque, A. (1988). Analysis of the organogenesis potential of calli of three Canary Island Lycopersicon esculentum landraces. Journal Plant Cell, Tissue and Organ Culture, 12(3):279-283.

[24] El-Bakry, A.A. (2002). Effect of genotypes, growth regulators, carbon source, and $\mathrm{pH}$ on shoot induction and plant regeneration in tomato. In Vitro Cellular and Development Biology-Plant, 38(5):501-507.

[25] Gubiš, J., Lajchová, Z., Faragó, J., and Jureková, Z. (2004). Effect of growth regulators on shoot induction and plant regeneration in tomato (Lycopersicon esculentum Mill.). Biologia, Bratislava, 59(3):405-408.

[26] Sheeja, T.E., Mandal, A.B., and Rathore, R.K.S. (2003). Efficient plantlet regeneration in tomato (Lycopersicon esculentum Mill.). Plant Tissue Culture, 14(1):45-53.
[27] Tran Thanh Van, K. (1981). Control of morphogenesis in in vitro cultures. Annals Review Plant Physiology, 32:291-311.

[28] Baraldi, R., Rossi, F., and Lercari, B. (1988). In vitro shoot development of Prunus GF 655-2: Interaction between light and benzyl adenine. Biology Plant, 74:440-443.

[29] Aloni, R., Aloni, E., Langhans, M., and Ullrich, C.I. (2006). Role of cytokinin and auxin in shaping root architecture: regulating vascular differentiation, lateral Root initiation, root apical dominance and root gravitropism. Annals of Botany, 97:883-893.

[30] Bajaj, Y.P.S. (1970). Effect of gammairradiation on growth, RNA, protein, and nitrogen contents of bean callus cultures. Annals of Botany, 34:1089-1096.

[31] Eroglu, Y., Eroglu, H.E., and Ilbas, A.I. (2007).Gamma ray reduces mitotic index in embryonic roots of Hordeum vulgare L. Advances in Biological Research, 1(1-2):26-28.

[32] Zhen, H.R. (1998). In vitro technique for selection of radiation induced mutants in sweet potato. In: In Vitro Techniques for Selection of Radiation Induced Mutations Adapted to Adverse Environmental Conditions. Proceeding of a Final Research Co-ordination Meeting organized by the Joint FAO/IAEA Division of Nuclear Techniques in Food and Agriculture, Shanghai, China. Pp. 79-82, IAEA, Veinna (2001).

[33] Omar, M.S., Yousif, D.P., Al-Jbouri, A.J., Al-Rawi, M.S., and Hameed, M.K. (1993). Effect of gamma rays and sodium azide on growth and cellular constituents of sunflower (Helianthus annuus L.) callus cultures. Journal of Islamic Academy of Sciences, 6:69-72.

[34] Khan, I., Gaj, M.D., and Maluszynski, M. (1999). In vitro mutagenesis in sugarcane callus culture. In: Mutation Breeding. Joint FAO/IAEA Division of Nuclear Techniques in Food and Agriculture and FAO/IAEA Agriculture and Biotechnology Laboratory. Pp. 19-21, IAEA, Vienna.

[35] Chagvardieff, P., Dimon1, B., Carrier, P., and Triantaphylides, C. (1989). Cell division arrest by gamma-irradiation in 
photoautotrophic suspension culture of

Euphorbia characias: Maintenance of photosynthetic capacity and overaccumulation of sucrose. Plant Cell, Tissue and Organ Culture, 19(2):141-149.

[36] Štajner, D., Milosevic, M., and Popović, B.M. (2007). Irradiation effects on phenolic content, lipid and protein oxidation and scavenger ability of soybean seeds. International Journal of Molecular Science, 8:618-627.

[37] Singh, P. (1996). Essentials of Plant Breeding. First edition, Kalyani Publishers, New Delhi, India.

[38] Ganesan, M., Bhanumathi, P., and Jayabalam, N. (2005). Mutagenic effects of sodium azide on somatic embryo regeneration and root growth of cotton (Gossypium hirsutum L. cv. SVPR2). Journal of Agricultural Technology, 1(2):365-380.

[39] Hofmann, N.E., Raja, R., Nelson, R.L., and Korban, S.S. (2004). Mutagenesis of embryogenic cultures of soybean and detecting polymorphisms using RAPD markers. Biologia Plantarum, 48(2): 173-177.

[40] Atanassov, A., Todorovska, E., Trifonova, A., Petrova, M., Marinova, E., Gramatikova, M., Valcheva, D., Zaprianov, S., and Mersinkov, N. (1996). Investigation of the somaclonal and mutagen induced variability in barely by the application of protein and markers. In: Application of DNA Based Marker Mutations for Improvement of Cereals and other Sexually Reproduced Crop Plants. Proceeding of a Final Research Coordination Meeting organized by the Joint FAO/IAEA Division of Nuclear Techniques in Food and Agriculture. Pp. 21-31, IAEA, Veinna.

Meeting organized by the Joint FAO/IAEA Division of Nuclear Techniques in Food and Agriculture, Shanghai, China. Pp. 6174, IAEA, Veinna (2001).
تهـــدف الدر اســـة الحاليــة الــى تحفيـز التغـــاير

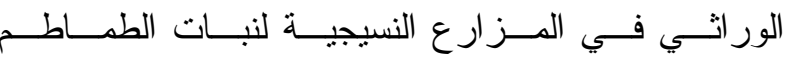

من خلال توظيف (Lycopersicon esculentum Mill.)

المطفرين الفيزيائي أشعة كاما و الكيميائي مادة أز ايد

الصوديوم. تم أختبار منظمات نمو نباتية مختلفة في

قابليتها على تحفيز نشوء الكالس وتكوين الاعضاء من

نموات خضرية وجذور. حفز الكالس على النشوء من

السويق الجنينية السفلية على وسط مار اشثيج وسكوج

(MS)

و (2, 4-D)2, 4-dichlorophenoxyacetic acid

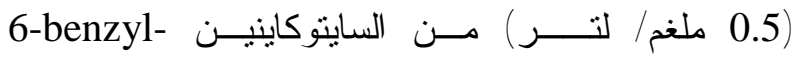

(BAP) aminopurine

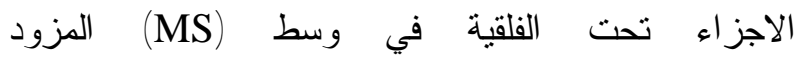

indole-3- acetic acid كلغ (0.8 ملغ/لتر ) من الاوكسين

(IAA) ومع (2ملغم/لتر ) من (BAP) . كما حفزت الجذور

على نفس الوسط ولكن باضافة (0.4 ملغم/لتز ) من

. (IAA)

شعتت مز ارع الكالس و البادر ات باثُعة كاما وبو اقع

ست جرعات (5، 15، 25، 35، 45 أو55) مليغري من

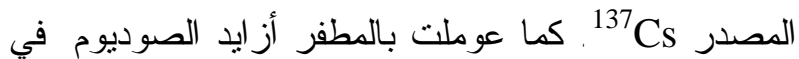

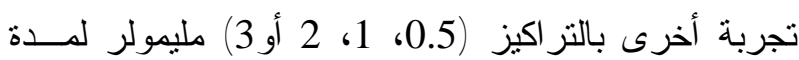

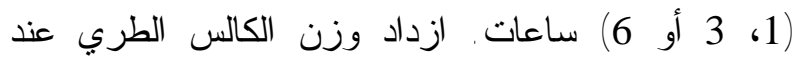

المعاملة (25) مليغري من أثنعة كاما وكذلك عند التركيزين

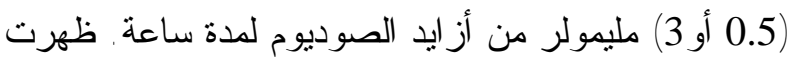

النموات الخضرية على كافة الاجز اء النباتية المفصولة من

الاجزاء تحت الفلقية التي عوملت بالاشعاع. ولم

تختلف المعاملة بالجرعتين (15 أو35) مليغري عن الن النعاع.

معاملة السبطرة. لوحظ تكوين الجذور على الاجز اء تحت

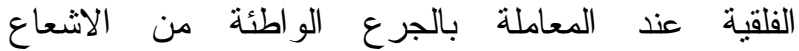

(5 أو15) مليغري فقط، في الوقت الذي ثثطت فيه المعاملة

بأز ايد الصوديوم ظهور النمو ات الخضرية و الجذور .

وظفت تقانة المؤشرات الجزيئية للدنا (RAPD)

للتحري عن الطفرات الوراثية المحتملة في عينات من

مستخلص الدنا. أستخلص الاخير من عينات بادرات النبات

الام أو من أنسجة الكالس المعرضة لجرعات اشعاعية 
مقدارها (15 أو45) مليغري وكذللك من الكالس المعامل

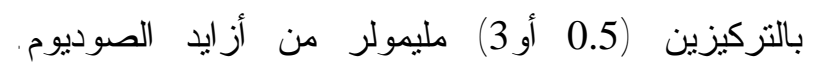

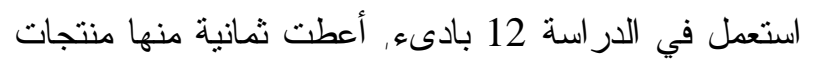
تضاعف. بلغ العدد الكلي لمنتجات التضاعف 27 حزمة.

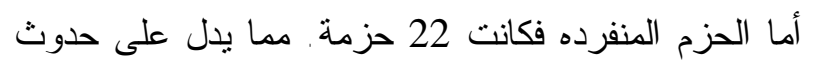
طفر ات ور اثية في خمسة منها. ففي الباديء

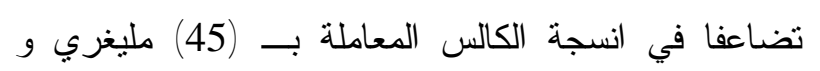

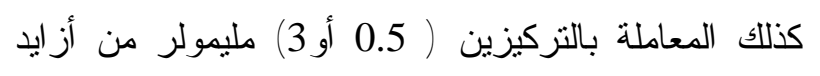

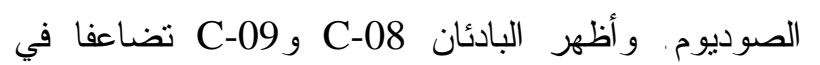
انسجة الكالس المشعع بالجرعة (15) مليغري. وجد بأن نقانة RAPD كانت فعالة في التحري عن الطفرات الور اثية المحتملة في أنسجة الكالس . 